\title{
RELATIONSHIP BETWEEN FLOW AND PERSONALITY TRAITS AMONG PRESCHOOL TEACHERS
}

\author{
Sanja Tatalović Vorkapić \\ Department of Educational Sciences, Faculty of Teacher Education, University of Rijeka, \\ University Avenue 6, 51000 Rijeka, Croatia \\ sanjatv@ufri.hr \\ Andreja Gović \\ Kindergarten “Gold fish,” Kostrena, Croatia
}

\begin{abstract}
The main objective of this study is to examine the relationship between the experience of flow on the job and personality traits among preschool teachers. The study was conducted on a sample of 96 teachers from six kindergartens in the area of Primorsko-goranska County, Croatia. Two questionnaires were applied in this study. The Flow Questionnaire was used to measure the flow and the Big Five Inventory was used to measure personality traits. The findings confirmed the hypothesis about high levels of extraversion, agreeableness, consciousness, openness to experience and flow, and low levels of neuroticism. Furthermore, the flow showed a significant positive correlation with extraversion, consciousness and openness to experience and negative with neuroticism. Extraversion decline with age was determined, too. This paper points out the significance of personality traits and experience of joy in the work among preschool teachers, with some implications of practice improvement.
\end{abstract}

Keywords: Big Five Personality model, early and preschool education, flow, preschool teachers

\section{INTRODUCTION}

The job of a preschool teacher requires many skills that can be acquired through formal education. However, often it can be heard from parents, children and coworkers 
that for some preschool teachers they say that they "have that certain something" to work with children and participants in the educational process. What could that "something" be? Was the preschool teacher born with these personality traits or is it something that is learned throughout their schooling and work with preschool children in kindergartens? Do the preschool teachers experience the feeling that they enjoy their work so much without being aware of the environment that surrounds them?! Does this affect the quality of work of a preschool teacher, and is this feeling associated with their personality traits? This research is directed precisely toward some of these issues and it will be attempted to provide answers to them, through an analysis of experience flow and personality of preschool teachers.

\section{Flow}

Surely, everyone has experienced a moment of feeling most comfortable, happy and fulfilled. In those moments, positive states appear in people including those that bring out in them a positive experience while performing a specific action or activity. Mihalyi Csikszentmihalyi $(1978,1997,2000)$ conducted research in which he wanted to find out why people engage in an activity, although they are not specifically rewarded for it. He researched chess players, climbers, dancers, composers who sometimes invest great efforts, which are difficult and risky. In the study he concluded that all the respondents had very positive experiences and he called these experiences flow i.e. infatuation. Infatuation or flow is an experience that occurs when we do an activity for which we are intrinsically motivated and that is under our control, but is challenging and requires skills and great concentration. This experience provokes in us a sense of not being aware of ourselves and our time flies by quickly (Rijavec, Miljković, Brdar, 2008). Flow is an experience that can happen while conducting different activities. Various studies list activities such as: reading, sailing, playing chess, alpine climbing, dancing, writing and group riding motorcycles as activities in which flow can often be experienced, while housework, watching TV and relaxing are activities that rarely lead to infatuation (Delle Fave, Massimini, 2004). Flow is an experience that has certain characteristics, seven in total, and Nakamura and Csikszentmihalyi (2002) have described them in detail. The first characteristic relates to the merging of activities and awareness. When a person is engaged in work that is challenging, all of their skills and capabilities which they possess should be included, and thus they become completely absorbed in what they do. All attention and energy is then focused on a particular activity. Thereby that activity becomes spontaneous, almost automatic and a person gets the feeling as if the activity and the person are combined into one unit. The next feature refers to the clarity of goals and feedback as one of the possible reasons why you can achieve a complete absorption in an activity. The clearer the goal to which a person strives, and the higher the rate of return information, the stronger the flow will be. One of the flow's properties is also a complete focus on the activity. People who experience flow are focused on an activity that is currently important to them. The concentration on a specific activity is in this case so large that the uncomfortable things and worries are completely ignored and neglected which is one of the reasons why the 
flow may have a significant impact on improving the individual's quality of life. One of the characteristics of flow is the sense of control over the situation. An individual who experiences the flow does not care about failure, because he has the feeling that everything is under control and that nothing unexpected can happen. Another property that greatly signifies the flow is the loss of self-awareness. Although it is in the human nature that individuals take care of themselves and care about impression that they leave on other people, this becomes less important during flow. Although this can be seen in everyday aspect of life, it is not true for the state of flow. The individual is so consumed with the activity he is engaged in that he doesn't even think about what others think of him. Moreover, self-esteem grows after having experienced flow because flow usually results in success in a difficult and challenging task. A feature that is often emphasized is the change in perception of the passage of time. Individuals who experience flow usually forget about time. Sometimes hours pass like minutes, and vice versa is possible as well. The author assumes that this happens because of the joy which is caused by the experience of flow, and which usually increases because of the feeling that the individual is free from the pressure of time. The final characteristic which is very important for the experience of infatuation is enjoying the activity itself. This characteristic is related to the skills that people have and that increase while practicing an activity. For example, if an individual begins to engage in an activity by force, after a while, as his skills grow, self-confidence appears which can result in this activity becoming a source of pleasure (Csikszentmihalyi, 1990). There are two types of activities. An activity that is an end in itself or a goal we call an autotelic activity, while an activity that is performed due to some external factors is called an egzotelic activity. The author believes that the majority of activities, which individuals perform, are of egzotelic nature, but there are exceptions when the activities are intertwined. For example, a musician is well paid for his work that puts him in the egzotelic activity, but on the other hand, he enjoys what he does which classifieds his work as an autotelic activity (Rijavec, Miljković, Brdar, 2008).

The experience of flow has been in the past thirty years attracting the attention of many scientists and researchers. Therefore, through these studies it was concluded that there is a correlation between flow and positive experiences and well-being. Guided by this information it can be stated that the more time is spent in the state of flow, the better the quality of the experiences. Included here are: a feeling of great concentration, creativity and experiencing more positive states and positive emotions. People do many professions. Work at these jobs is universal, but also different and it should be important to each individual that they do the job that makes them happy and fulfilled. We should emulate the saying of Thomas Carlyle, which reads: "Blessed is he who has found his work; let him ask no other blessedness" (Csikszentmihalyi, 2006, p. 270). In America between 1972 and 1973 a big national research was conducted which obtained the biggest evaluation of work satisfaction. 52\% of employees responded that they were very satisfied with their job, while only $3 \%$ were dissatisfied. Furthermore, employees cited three reasons for job dissatisfaction: lack of variety and challenges at work, conflicts with co-workers and feeling exhausted, which involves too much pressure, and stress at work. Respondents indicated that the most positive experiences in their life were experienced 
on the job. Therefore, it can be assumed that people like to work and are very motivated to work (Csikszentmihalyi, 2006). Taking into account all of the above mentioned, it can be concluded that individuals who experience flow at work perform their job better, feel happier and more fulfilled and their self-esteem grows when they experience success at work.

In a study conducted on the topic "Optimal experiences at work and during leisure time of teachers and doctors," all teachers and $80 \%$ of doctors confirmed the existence of optimal experience in their lives. For teachers optimal experiences are: reading, engaging in a hobby, teaching, sports, listening to music and studying. Unlike teachers, doctors put their job in the first place, and only after that hobbies and other as a source of optimal experience. When it comes to work, teachers cited regular work experience, while doctors cited surgical operations as sources of optimal experience at work. In addition, positive work experiences for both professions are: good relations with the colleagues, students and patients. While negative experiences for teachers are the student's failure to show interest in the teaching, and failures for doctors, pressures and poor relations with colleagues. Relations between the work they do and leisure time are connected with each other. Both professions see the acquisition and development of knowledge as part of personal growth and the development of the connection of manual and technical competences with theoretical knowledge. The conclusion of the study was that in both professions there is a correlation between the quality of early experiences and early performance and the impact on the well-being of students and patients (Rijavec, Miljković, Brdar, 2008).

A study conducted in the U.S. utilized the method of sampling experiences. It was an attempt to determine whether a person gains more positive experiences at work or at home. Due to the research aim, the respondents wore an electronic transmitter during the period of one week. As a response that the examiners received eight times a day for one person, the respondents filled in the booklet what they did and how they felt. 33\% of respondents claimed to have experienced the feeling of flow or "state of a fascinating infatuation". This implied that the respondents experienced above average levels of challenges and skills, which were prerequisites for experiencing feelings of infatuation. 4800 responses were collected in the research, which would account for an average of 44 responses per week for one person. The researchers concluded that people who were often in a state of "fascinating infatuation" i.e. experienced flow felt strong, active, creative, focused and motivated. Interestingly, $54 \%$ of the responses about the experience of flow occurred when the respondents were doing their job. This fact leads to the conclusion that the respondents are faced with outstanding challenges and above-average use of their skills more than half of their working time (Csikszentmihalyi, 2006).

There was little difference between the respondents who are engaged in highranking jobs and lower-ranking jobs. Managers and supervisors often experience flow, $64 \%$ of them, $51 \%$ of clerks and $47 \%$ of respondents who are engaged in manual work. $20 \%$ of manual workers experience the flow in their free time, and $16 \%$ of clerks and $15 \%$ of managers who show that there is a greater percentage of experience of flow at work than during leisure time. Respondents noted having more experiences that are positive when they underwent the feeling of flow. The survey showed that the respondents wanted 
to do another job even though they experienced a sense of flow in the work they do. Although they were highly motivated to work and work provided them with a source of pleasure, they nevertheless wanted to change it. A possible explanation for this response is that, when it comes to work, individuals do not pay attention to the feelings and they their job is an obligation and it seems to them like a burden (Csikszentmihalyi, 2006).

\section{Personality traits}

"Personality can be defined as a set of psychological traits and mechanisms within the individual that are organized and relatively permanent, and affect the interaction and adaptation of the individual to the intrapsychic, physical and social environment" (Larsen, Buss, 2007, p. 4). In describing personality traits, many authors differ in their approach. Some psychologists define "personality traits as an internal (or hidden) properties of the individual which cause their behavior", others use personality traits to "describe permanent aspects of one's behavior," while some other define personality traits "as descriptive summaries of an individual's characteristics" (Fulgosi, 1983). The latter traits do not imply neither internal nor causative, but expressed behavior. Proponents of such a description of personality traits claim that first individual differences among individuals need to be determined and identified, and only then can theories be developed that can be causal in nature, so consequently they can be described. For decades, psychologists have been dealing with the problem how to identify all the personality traits and how to fit them into one system that would apply to all. They concluded that taxonomy of personality traits is necessary in order to facilitate communication among researchers and scientists engaged in this topic (Kardum, Gračanin, Krapić, 2007). Some of the more important taxonomies that have an empirical and theoretical justification are: Eysenck's hierarchical model of personality, Cattell's taxonomy as a system of 16 personality factors and many others (Larsen, Buss, 2007). The initial theoretical model of personality in this work is the Five-factor model because it belongs to the model that has had the greatest empirical validation with regard to the possibility of a comprehensive personality description. The Five-factor model comes from studies of personalities that people use in everyday language, i.e. from a combination of lexical and statistical approaches (McCrae, John, 1992). The Five-factor model of personality consists of five famous personality traits, which are: Extraversion, Agreeableness, Conscientiousness, Emotional Stability, and Openness to Experience (John, Srivastava, 1999).

This raises the question whether all preschool teachers have all these personality traits? Does the lack of some traits affect the work of preschool teachers? Guided by the theoretical framework of the Five-factor taxonomy of personality, as in previous research (Author, 2012), it can be assumed that the extraverted, agreeable, conscientious, emotionally stable and open preschool teachers are extremely desirable in the context of work demands in an institutions for early and preschool education (Author1, 2013; Author2, 2013). Extraverted preschool teachers will be open to the child and committed to everything that happens in relation to the child. Preschool teachers who are extraverted are dynamic and full of energy, and take an active approach to problem solving. They will 
not mind if the child often interrupts them. They like to talk and can also be intrusive toward a child (Brajša, Brajša-Žganec, Slunjski, 1999). Pleasant preschool teachers could have the motto "let's get along" (Larsen,Buss, 2007). Preschool teachers with personality traits such as compassionate, kind, warm and full of understanding refers to the child with respect. He makes agreements with the child and his warm relationship devotes to the child his energy and time. It will be important to such a preschool teacher that the relationship with all participants in the educational process is harmonious. Preschool teachers that are conscientious will attach great importance to the work and to obeying the rules. (S)he will establish a deep and lasting relationship with the child, but will ask him to respect mutually agreed rules. This preschool teacher shows characteristics such as organization, practicality, tidiness, acquiring knowledge as well as cleaning and sorting toys and materials according to the rules. Emotional stability is very important for preschool teachers whose work can be very stressful and where he is faced with everyday problems and events. Since a preschool teacher is a model from whom a child learns from an early age about everything that surrounds him, it is essential that the preschool teacher is emotionally stable, that (s)he does not often change his/her mood because in this way the child loses confidence in the preschool teacher. Emotional instability i.e. neuroticism may adversely affect the work of preschool teachers because it will "sabotage" their own work and thus may compromise the safety of children. A preschool teacher with the predominant personality trait of openness will be "eager" to experience new challenges and activities. They will be open to the child, will use all their senses and will attempt to move and activate the child as much as possible. The preschool teacher is constantly on the move, does not like routine and can sometimes be impulsive. With a child, they will achieve a friendly relationship and will together enjoy the relaxation and fun (Brajša, Brajša-Žganec, Slunjski, 1999).

\section{Flow and personality traits among preschool teachers}

In the process of education, a preschool teacher acts primarily on the education of the child and on all participants in the educational process with the overall behavior and personality traits. Preschool teachers require pedagogical and psychological knowledge for a quality approach to working with children, but this should not mean that there will always be a guarantee for their quality work. Therefore, it is essential what the preschool teacher is like i.e. it is not only important what he knows but what he is. Hamachek's confirms this $(1999$, p. 209) by the state: "Consciously we teach what we know; unconsciously we teach who we are". This refers to the personality traits that (s)he owns, his/her lifestyle and other. Worldviews of preschool teachers, their temperament, their beliefs and values substantially determine a preschool teacher (Author1, 2014). All this determines the preschool teachers as well as what they are, what is and what is not important in their life, how they react to new situations, what kind of impact they have on their environment (Author2, 2014). The preschool teachers' behavior towards the child will depend on all of this as well as on what kind of environment they will create for a proper growth and development of the child. It is important which materials 
they will offer in their work, in what way they will encourage communication between all children, what their attitude toward creativity and innovation of children and coworkers will be (Author3, 2014). Following the data available in the literature, it can be assumed that the preschool teacher who possesses personality traits of extraversion, agreeableness, conscientiousness, openness and emotional stability will be able to enjoy their work and will come to experience the feeling of flow in their work. In other words, a significant correlation is expected between these personality traits and greater flow (Baumann, 2012). The aforementioned personality traits have a positive sign when it comes to psychological health while the personality trait of neuroticism has a negative sign and it is assumed that a preschool teacher who possesses traits of neuroticism will not be able to experience flow at work.

From the aforementioned it is observable that the work of a preschool teacher requires a lot of energy, knowledge, creativity, innovation, freedom, love for children, understanding and other. Because of creativity, innovation, freedom of choice, diversity, challenges and other, the job of preschool teachers is the kind of work that rejoices and fulfills. However, sometimes it can be exhausting therefore, the preschool teachers should regularly update their energy and regularly work on themselves, i.e. "reflection" is necessary. A reflective preschool teacher is an aware preschool teacher who seeks to find out how children and adults perceive him, how he influences all participants and how others affect him. Therefore, one should follow the saying "anyone who in any way wants to influence or support the development of another person, should engage in the raising of consciousness and continuation of their own development." (Slunjski, 2004, p. 25). When preschool teachers do the job they love and it is the source of their happiness and satisfaction, then it is possible that they often experience a feeling of flow. Then preschool teachers are fulfilled, they gain positive experiences and emotions and are more satisfied in all spheres of life. They will be focused on what they are doing, come up with more creative and innovative ideas, which will greatly contribute to the quality of work with children and other participants in the educational process. The work of a preschool teacher will be considered as creative, innovative, challenging, spontaneous, and all these constitute the conditions for experiencing flow at work.

\section{THE AIM, PROBLEMS AND HYPOTHESES OF RESEARCH}

The main objective of this study was to examine the relationship between the experience of flow at work and personality of preschool teachers. From the above research objective, the following problems arose:

1) Examine the level of experience of flow at work and personality traits among preschool teachers;

2) Examine the relationship between the experience of flow at work and personality of preschool teachers;

3) Examine the relationship of age and work experience of preschool teachers with their flow and personality traits; and 
4) Examine the differences in the level of flow experience among preschool teachers who had a desire to become preschool teachers and those who wanted to engage in some other occupation.

Based on the findings of previous research and relevant literature, the following hypotheses were formed:

H1: An increased level of flow with work is expected. Also, elevated levels of extraversion, agreeableness, conscientiousness and openness to experience are expected, and decreased levels in neuroticism.

$\mathrm{H} 2$ : A significant relationship between the level of flow and neuroticism is not expected, while it is expected with the remaining personality traits in the positive direction.

H3: A significant relationship between socio-demographic variables, personality traits and flow at work is not expected, except between age and extraversion in the negative direction.

H4: It is expected that the experience of flow at work will be significantly higher among preschool teachers who had a desire to work as preschool teachers, as opposed to those who had a desire to do some other job.

\section{METHOD}

\section{Subjects}

The study was conducted on a sample of 96 preschool teachers from six kindergartens and six cities in Primorsko-goranska County: Kostrena $(N=10)$, Kraljevica $(N=15)$, Bakar $(N=17)$, Crikvenica $(N=18), \operatorname{Krk}(N=10)$ and Novi Vinodolski $(N=26)$. From a total of 96 preschool teachers who participated in the study, all subjects were female. The average age of respondents was $M=37.59$ ( $S D=10.83$ ), and the age range 22-64 years. Results of the Kolmogorov-Smirnov test showed that the age distribution does not significantly differ from the normal distribution $(K-S z=1.18, p=0.12)$, which enables the use of parametric tests in subsequent statistical analyses.

The average work experience among these preschool teachers is $M=3.11(S D=9.38)$ years, with a range from 2 months to 35 years. Also, the results of the KolmogorovSmirnov test showed that the distribution of work experience in the kindergarten where respondents are currently employed is not significantly different from the normal distribution $(K-S z=1.33, p=0.06)$, which also enables the use of parametric tests.

In the study, the respondents were asked to state the occupation which they have always wanted to follow. These were the responses: preschool teacher, preschool teacher/ primary school teacher, teacher of music education, veterinarian, botanist/preschool teacher, preschool teacher/physiotherapist/primary school teacher, kinesiologyst/ preschool teacher/psychologist, journalist/writer, veterinarian/preschool teacher/ inclusive-education teacher, preschool teacher/foreign language teacher, to work with 
children, teacher, academic musician, preschool teacher/professor/pedagogist, musician, primary school teacher, doctor, actress, primary school teacher/florist. Of these, two groups of preschool teachers were created for the following analysis: those who wanted to be preschool teachers $(N=58)$ and those who wanted a different profession $(N=28)$. One preschool teacher did not answer on this question.

\section{Measures}

Two questionnaires were used in the study. The Flow questionnaire was used to measure flow at work (Csikszentmihalyi \& Csikszentmihalyi, 1988), and the BFI was used to measure dimensions of the five factor personality model (Big Five Inventory; BenetMartinez \& John, 1998), i.e. its adapted Croatian version (Kardum, Hudek-Knežević, Kola, 2005). Both questionnaires were used to assess the respondents estimations on the Likert's scale of 5 degrees by entering the corresponding numeric values depending on to which extent they agree or disagree with the given statements ( $1=$ completely disagree; $2=$ partly disagree, $3=$ neither agree nor disagree; $4=$ partly agree; $5=$ strongly agree). Both measuring instruments demonstrated satisfactory levels of reliability, Cronbach alpha type. The Flow questionnaire consisted of 12 items (item example: "I am preoccupied with what I'm doing") and was used to examine levels of the respondents' flow experience at work. By analyzing all the data, the overall level of flow at work is obtained. The Big Five Inventory consists of 44 items, which have the characteristic of brevity and clarity. Openness to experience subscale contains 10 items (item example: "Is curious and interested in a number of different things"); Conscientiousness subscale contains 9 items (item example: "Performs her work responsibly"); Neuroticism subscale consists of eight items (item example: "Is depressed, sad"); Extraversion subscale contains eight items (item example: "Is open and social"); and the Benefits subscale consists of nine items (item example: "Is ready to help and is selfless").

\section{Procedures}

Research began with an agreement on the implementation of research with the principals of kindergartens from the above mentioned cities (Gović, 2012). Therefore, along with the inquiry letters written consents of the principals were obtained. Researchers have personally delivered the questionnaires to each preschool institution. During the delivery of the questionnaire, the purpose of the research has been explained in detail to the respondents. At the same time, it was emphasized that the questionnaire is anonymous, that the results will be analyzed at the group level and that the respondents' privacy is guaranteed. All respondents were promised feedback regarding research results. In agreement with the authorities, each institution should have submitted the completed questionnaires to the appointed place within seven days. The entire process of data collection lasted for three months. 


\section{RESULTS AND DISCUSSION}

\section{Flow and personality traits among preschool teachers}

Results of the Kolmogorov-Smirnov test showed that the distribution of the flow results had negatively skewed distribution which was significantly different from the normal distribution $(K-S z=1.56, p=0.02)$. This finding implied at the application of non-parametric tests in subsequent statistical analyses. Results of the KolmogorovSmirnov test showed that the distribution of the results of personality traits: Openness to experience $(K-S z=0.67, p=0.76)$, Conscientiousness $(K-S z=1.16 p=0.13)$, Neuroticism $(K-S z=0.77 p=0.59)$, Extraversion $(K-S z=0.92 p=0.37)$ and Agreeableness $(K-S z=1.6$ $p=0.21$ ) do not significantly differ from the normal distribution, which enables the use of parametric tests in subsequent statistical analyses.

Table 1. Descriptive parameters (means, standard deviations and ranges) and corelation coefficients of flow and personality traits in preschool teachers

\begin{tabular}{|l|l|l|l|l|}
\hline & $M$ & $S D$ & Range & $\begin{array}{l}\text { Correlation } \\
\text { coefficients }\end{array}$ \\
\hline Flow & 47.39 & 4.53 & $28-56$ & Flow \\
\hline Extraversion & 29.53 & 4.92 & $14-40$ & $\mathbf{0 . 2 0 2 *}$ \\
\hline Agreeableness & 36.37 & 4.41 & $25-45$ & -0.018 \\
\hline Consciousness & 36.10 & 4.36 & $20-45$ & $\mathbf{0 . 2 5 9}$ \\
\hline Openness to experience & 39.65 & 4.34 & $30-49$ & $\mathbf{0 . 2 2 8 *}$ \\
\hline Neuroticism & 18.22 & 4.61 & $9-31$ & $\mathbf{- 0 . 3 1 5 * *}$ \\
\hline
\end{tabular}

$*_{p}<0.05 ; * * p<0.01$

Flow at work. The obtained results (Table 1) show that a rather high level of flow at work is present among the preschool teachers who participated in this study. From a maximum of 60 points which could be achieved with the questionnaire, respondents showed an average response value of 47.39 which indicates a very high value of the obtained result within possible range. A possible explanation for such high levels of flow in the results lies in the description of the preschool teachers' profession. The work of a preschool teacher offers on a daily basis numerous opportunities, new challenges, finding solutions; includes creativity, imagination, innovation. Therefore, the job of preschool teachers is considered by many as an interesting job in which every day offers a multitude of challenges that the preschool teacher should and must respond to in order to successfully perform their job (Author1, 2014). 
Personality traits. The determined levels of the personality traits of respondents confirm previous findings of similar studies (Author, 2012; Author1, 2013). It is reasonable to expect that preschool teachers have highly expressed traits of extraversion, agreeableness, openness, conscientiousness and emotional stability, since it makes all the prerequisites of a competent performance of all tasks within the work in institutions for early and preschool education.

\section{Relationship between flow and personality traits among preschool teachers}

In further analysis, based on the respondents' responses, the relationship between the experience of flow at work and the preschool teachers' personality traits (extraversion, agreeableness, conscientiousness, openness, neuroticism) were analyzed. With this aim, a correlation analysis was conducted and results could be observed in Table 1, too. Even generally low, positive significant correlation was determined between flow and the following personality traits: extraversion, conscientiousness and openness, which would mean that with increasing levels of these personality traits, preschool teachers' level of flow grows as well. Preschool teachers who express the traits of extraversion are dynamic, full of energy, talkative and can also be intrusive. They are fully immersed in their job and like to play "the big role". More extraverted preschool teachers are usually happier people who often experience emotions with positive tone, which greatly affect their mental and physical health (Baumann, 2012). Therefore, this finding on the significant association with flow at work was expected. The more pronounce extraversion is with preschool teachers, the greater the likelihood of experiencing flow at work. Preschool teachers who have pronounced personality traits of conscientiousness and enthusiasm love their work and are committed to their work. A person with the predominant personality trait of conscientiousness enjoys their work in which they may affect compliance with the agreed rules, convenience and organization, and precisely because of that their flow at work is possible. Therefore, the established significant positive correlation of this trait and flow confirms the aforementioned. Positive correlation of flow experience and openness to experience is statistically significant, as can be seen in Table 1. Preschool teachers with this trait are open to new experiences and therefore it is possible to assume that there will be a greater possibility for experiencing flow. The obtained results are logical because of the very nature of the listed personality traits. Therefore, preschool teachers that are open, conscientious, who seek new challenges and activities, like rules, are sociable, etc., will more likely experience flow at work. In contrast, a significant negative correlation was found between flow at work and neuroticism, what was expected. A preschool teacher who has personality traits that correspond to neuroticism are unreliable, experience internal dissatisfaction, are poorly motivated for their job, often complain and change moods. The main property of neuroticism is a high level of emotional instability and reactivity. So, it can be assumed that these characteristics of neuroticism "prevent" a preschool teacher to experience a sense of flow at work as well as opportunities to fully immerse themselves into work, which may be in the background of this significantly negative correlation. Previous research findings on the relation between personality 
traits and life satisfaction support the established findings. These studies pointed out that personality traits are important predictors of life satisfaction (Bratko, Sabol, 2006; Author 1,2013). Extraversion, agreeableness and conscientiousness are positive predictors, whereas neuroticism is a significant negative predictor. Neuroticism is associated with the experience of anxiety, nervousness, sadness and unpleasant emotions, which prevent persons with such traits to be satisfied with their lives. The data obtained from studies conducted on students of the University of Zagreb, in which the role of self-esteem in relation to personality traits and nonverbal social skills were explored, contribute to the confirmation of the results of this research. Students who have achieved higher scores on the scale of emotional endurance have expressed traits of extraversion, benefits and neuroticism. Extraversion and agreeableness are defined in terms of open, active, sociable i.e. positive aspects. While, on the other hand, neuroticism is negatively associated with emotional endurance because people who are prone to anxiety, irritability, negativity have difficulty with emotional expression (Burušić, Tadić, 2006).

Also, the obtained data in this study is further supported by data obtained in the work of Krapić (2005). This study demonstrated that there is a correlation between personality traits of the five-factor model with some work behavior: career and occupational choice, training and education, individual job performance, counterproductive work behavior, accidents at work, group processes and team performance. The obtained data confirmed that the personality trait of Conscientiousness stands out among individuals already during job search efficiency in building a career, individuals in the workplace are more motivated, more than others adhere to the working instructions and are less likely to show some forms of counterproductive work behavior. Conscientiousness is suitable for tasks that require creativity, and is more suitable for group work, too. Neuroticism or emotional stability is also a very important dimension for behavior related to work. Neuroticism has proven harmful to group performance, while on the other hand, emotional stability is associated with better individual performance. Individuals with higher personality trait of extraversion will be more active in finding a job and building a career, it is more likely that they find employment faster, and they will be somewhat more successful in the workplace, especially if they are working in jobs that require social interaction such as vendors and group work.

\section{Relationship of age and work experience with flow and personality traits among preschool teachers}

In further analyzes the relationship between age and work experience of preschool teachers was examined with their levels of flow and personality traits by means of the implementation of correlation analyses. Correlation coefficients can be seen in Table 2 . By closely analyzing the Table 2 , it could be seen that the only significant correlations were observed between age and years of work experience with extraversion. By observing the established relationship between subjects' age and extraversion, it was found that younger preschool teachers and those with less years of work experience in the kindergarten, in which they are currently employed, are significantly more extraverted, sociable 
and communicative. In addition, there were no significant correlations between other personality traits and flow with age and length of service. The study of Author (2012) also established a tendency toward significant negative correlation between work experiences in general and extraversion. This finding was expected due to the age-related decline in extraversion (Bratko, Sabol, 2006), with this group of respondents, i.e. the preschool teacher does not differ with respect to any other profession.

Table 2. Correlation coefficients of age and work experience with flow and personality traits among preschool teachers

\begin{tabular}{|l|l|l|}
\hline & Age & Work experience \\
\hline Flow & -0.015 & -0.083 \\
\hline Extraversion & $\mathbf{- 0 . 3 1 9 * *}$ & $\mathbf{- 0 . 3 0 4 * *}$ \\
\hline Agreeableness & -0.193 & -0.178 \\
\hline Consciousness & -0.130 & -0.164 \\
\hline Openness to experience & -0.112 & -0.133 \\
\hline Neuroticism & 0.178 & 0.172 \\
\hline
\end{tabular}

${ }^{*} p<0.05 ; * * p<0.01$

\section{The analysis of flow between preschool teachers who wish to have this job and those preschool teachers who wish to have some other job}

In order to simplify the determination of the level of experience of flow at work and the respondents' wish of profession that they have mostly wanted to perform, their answers were classified into two categories. As stated before, the first category includes respondents who expressed a desire to become only preschool teachers $(N=58)$, and the other ones who wished to engage in some other profession $(N=28)$. In order to analyze the differences in the level of experience of flow among preschool teachers who had the desire to become preschool teachers and those who wanted to engage in some other occupation, a non-parametric Mann Whitney test was carried out, since it was determined that the distribution of flow is significantly different from normal. The obtained results show that there was no significant difference in the experience level of flow at work in relation to these two categories of preschool teachers $(z=-1.15, p=0.25)$. This difference is shown in Figure 1.

The fourth hypothesis was not confirmed. Indeed, although the difference was not statistically significant, a tendency of greater flow at work was found among those preschool teachers who have declared to have wanted to engage in some other occupation. The obtained results show that in the first group of preschool teachers the average value 
is $M=47.43$, and in the second group of preschool teachers it is $M=48.28$. A possible reason for this is that they by doing the work of preschool teachers which was not their first choice they realized the "charms" of this occupation. Work of a preschool teacher provides freedom, evokes creativity, innovation, and they were able to accomplish various dimensions of work which were their first choice of occupations. Csikszentmihalyi (2006) notes that the work can be a pleasant, even the most pleasant part of life. Sometimes the daily tasks at work turn into experiences of flow and the work that people do every day becomes a pleasure and sometimes the work cannot be distinguished from leisure time. If people had the chance to choose their occupation again, their choice would always be the same because people "find" themselves in their work and it gives them a sense of satisfaction and fulfillment.

Figure 1. Averages of the flow in the group of preschool teachers who wish to become preschool teachers (first category) and in the group of preschool teachers who wish to have some other job (second category)

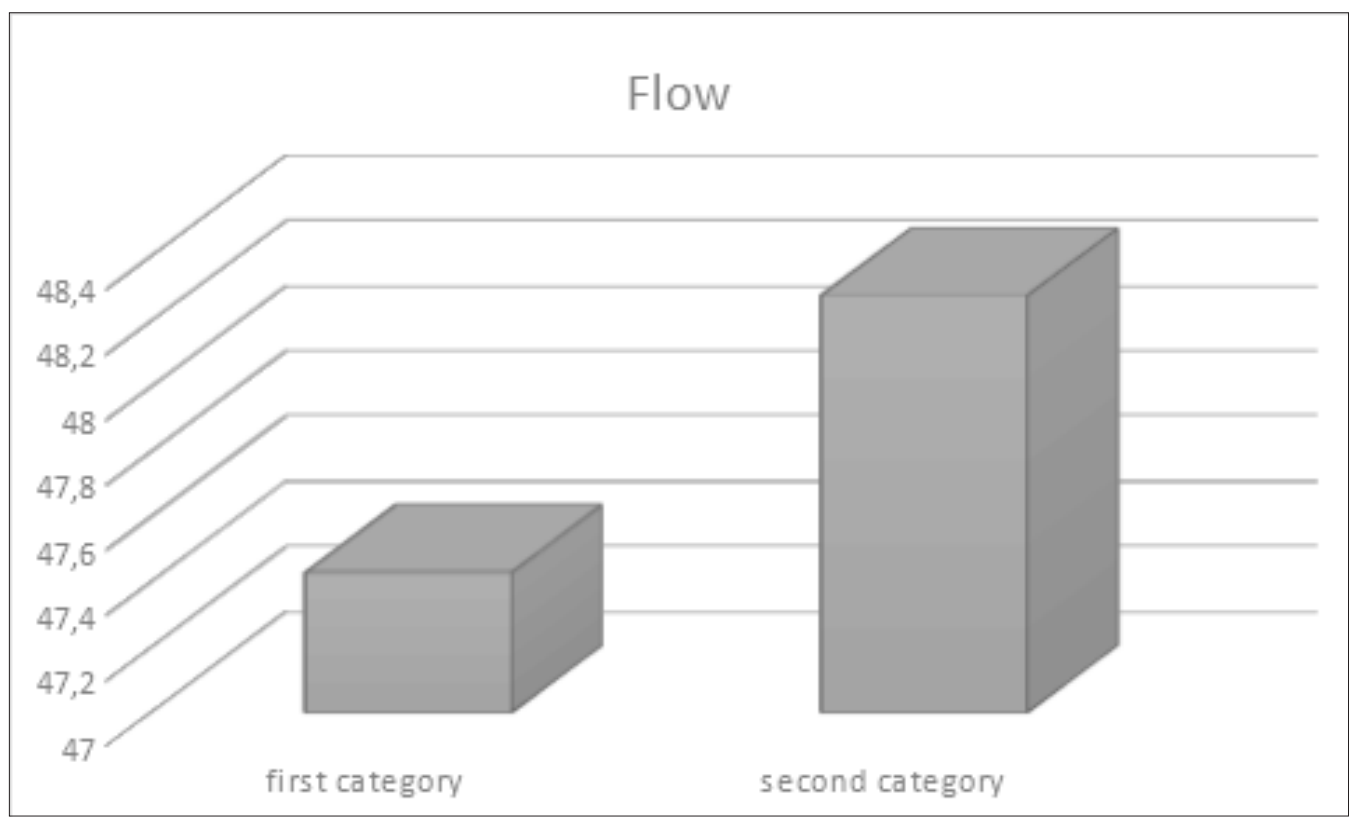

\section{CONCLUSION}

Given the basic objective of this research, which was to examine the relationship between the experience of flow at work and personality of preschool teachers, the following was determined. First, an elevated level of flow at work was established among the examined preschool teachers, as well as elevated levels of personality traits: extraversion, agreeableness, conscientiousness and openness to experience, and significantly lower 
level of neuroticism. Given the theoretical background and previous research, it was to be expected that preschool teachers would show a higher level of described variables, which confirmed the first hypothesis. Second, a significant positive correlation was determined between personality traits: extraversion, conscientiousness and openness to experience with the experience of flow at work, and a negative significant relationship of flow with neuroticism. With an increase in the personality traits of extraversion, conscientiousness and openness, grows the experience of flow as well, while with neuroticism it is not the case, which was also expected. Furthermore, the analysis of age and years of work experience with the focus variables, determined only a significant negative correlation of age and years of work experience with extraversion, which confirms previous research, regardless of the type of profession of respondents who participated in the study. Finally, no significant difference in the experience level of flow at work in relation to preschool teachers who had a desire to work as preschool teachers was determined, as opposed to those who had a desire to do another job, although this was expected. The tendency toward greater flow at work was found among those preschool teachers who initially wanted to engage in some other occupation, which is an interesting finding and certainly worthy of further analysis in future research.

A preschool teacher is a person who is of crucial importance for the proper growth and development of early age children. Following the expression "first three years are the most important" and knowing how important a preschool teacher is in a child's life, it is necessary to "raise" the role and importance of the profession of preschool teachers of early age children to a "higher" level. Because of the general lack of objective research on preschool teachers of young children and their work, but also because of flow and personality traits, analyses were performed using a significant contribution to the field of positive psychology in the context of work in kindergartens. Although the study has some limitations that apply to a relatively small number of respondents, however, it may represent a solid base for further research in this area. Also, it would be interesting to compare the data obtained from this study with data from other samples of respondents, for example, preschool teachers who enrolled in lifelong education, preschool teachers from various counties, cultures, and preschool teachers of the opposite gender. As for the results of this research, they certainly give a new "look" at preschool teachers, and emphasize the importance of not only their personality but also of the internal resources for the competence of experiencing flow and commitment to the work place.

Acknowledgement: This research is the part of an undergoing project: „Professional Development of Teachers: Reputation, Personality and Transversal Competencies"13.10.2.2.02, a grant financially supported by the University of Rijeka, Croatia. 


\section{REFERENCES}

1. Baumann, N. (2012). Autotelic personality. In: S. Engeser (Ed.), Advances in flow research (pp. 165-186). New York: Springer.

2. Benet-Martinez, V., John, O. P. (1998). Los cincos grandes across cultures and ethnic groups: Multitrait multimethod analyses of the Big Five in Spanish and English. Journal of Personality and Social Psychology, 75: 729-750.

3. Brajša, P., Brajša-Žganec, A., Slunjski, E. (1999). Tajna uspješnog roditelja i odgajatelja. CASH, Pula.

4. Bratko, D., Sabol, J. (2006). Osobine ličnosti i osnovne psihološke potrebe kao prediktori zadovoljstva životom: rezultati on-line istraživanja. Društvena istraživanja, 4-5 (84-85): 7693-7711.

5. Burušić, J., Tadić, M. (2006). Uloga samopoštovanja u odnosu crta ličnosti i neverbalnih i socijalnih vještina. Društvena istraživanja, 4-5 (84-85): 753-771.

6. Csikszentmihalyi, M. (1978). Attention and the holistic aproach to behavior. In: K. S. Pope \& J. L. Singer (Eds.), The stream of consciousness (pp. 335-358). New York: Plenum.

7. Csikszentmihalyi, M., Csikszentmihalyi, I. S. (1988). Optimal Experience: Psychological studies of flow in consciousness. Cambridge: Cambridge University Press.

8. Csikszentmihalyi, M. (1990). Flow: The psychology of optimal experience. New York: Harper-Collins.

9. Csikszentmihalyi, M. (1997). Finding Flow. New York: Basic Books.

10. Csikszentmihalyi, M. (2000). Beyond boredom and anxiety. Experiencing flow in work and play. San Francisco: Jossey-Bass. (Original work published 1975)

11. Csikszentmihalyi, M., (2006). Zanesenost: Očaravajuća obuzetost. Zagreb: Naklada Slap.

12. Delle Fave, A., Massimini, F. (2004). Bringing subjectivity into focus: optimal experiances, life themes and person-centred rehabilitation. In: P.A. Linley \& S.Joseph (Eds.), Positive Psyhology in Practice (pp. 581-597). London: Wiley \& Sons.

13. Fulgosi, A. (1983). Psihologija ličnosti: Teorije i istraživanja (Personality psychology: Theory and research. In Croatian). Zagreb: Školska knjiga.

14. Gović, A. (2012). Doživljaj zanesenosti na poslu i osobine ličnosti odgajatelja. Master thesis. Faculty of Teacher Education, University of Rijeka, Croatia.

15. Hamachek, D. (1999). Effective teachers: What they do, how they do it, and the importance of self-knowledge. In. R Lipka \& T. Brinthaupt (Eds.), The role of self in teacher development (pp. 189-224). Albany, NY: State university of New York Press.

16. Author3 (2014).

17. John, O. P., Srivastava, S. (1999). The Big Five trait taxonomy: History, measurement, and theoretical perspectives. In: L. Pervin \& O. P. John (Eds.), Handbook of personality: Theory and research (2nd ed. pp. 102-138). New York: Guildford Press.

18. Kardum, I., Gračanin, A., Krapić, N. (2007). Odnos dimenzija petofaktorskog modela ličnosti i raspoloženja. Društvena istraživanja, 1-2(87-88): 135-156. 
19. Kardum, I., Hudek-Knežević, J., Kola, A. (2005). Odnos između osjećaja koherentnosti, dimenzija petofaktorskog modela ličnosti i subjektivnih zdravstvenih ishoda. Psychological Topics, 14(2): 79-94.

20. Krapić, N. (2005). Dimenzije ličnosti petofaktorskog modela i radno ponašanje. Psychological topics, 14(1): 39-55.

21. Larsen, R. J. \& Buss, D. M., (2007). Psihologija ličnosti. Zagreb: Naklada Slap.

22. McCrae, R. R., John, O. P. (1992). An introduction to the five-factor model and its applications. Journal of Personality, 60: 175 -215.

23. Nakamura, J., Csikszentmihalyi, M. (2002). The concept of flow. In: C. R. Snyder \& S. J. Lopez (Eds.), Handbook of positive psychology (pp. 89-105). New York: Oxford University Press.

24. Rijavec, M., Miljković, D., Brdar, I. (2008). Pozitivna psihologija. Zagreb: IEP-D2. 25. Slunjski, E. (2004). Devet lica jednog odgajatelja/roditelja. Mali profesor d.o.o. Zagreb. 